\title{
Inundation simulation for urban drainage basin with storm sewer system
}

\author{
M.H. Hsu, S.H. Chen, T.J. Chang* \\ Department of Agricultural Engineering, Hydrotech Research Institute, National Taiwan University, 1, Roosevelt Rd. Sec. 4, \\ Taipei 10617, Taiwan, ROC
}

Received 15 October 1999; received in revised form 21 March 2000; accepted 23 March 2000

\begin{abstract}
An urban inundation model, combining a storm sewer model SWMM, two-dimensional (2D) diffusive overland-flow model and operations of pumping stations, has been developed to simulate inundation in urban areas caused by the surcharge of storm sewers and outlet pumping stations. The movement of water in the studied urban watershed is characterized by two components, namely, the storm sewer flow component and the surcharge-induced inundation component. SWMM is employed to solve the storm sewer flow component and to provide the surcharged flow hydrographs for surface runoff exceeding the capacity of the storm sewers. The 2D diffusive overland-flow model considering the non-inertia equation with Alternative Direction Explicit numerical scheme is then used to calculate the detailed inundation zones and depths due to the surcharged water on overland surface. Drainage by pumping stations at outlets of the storm sewer system has also been taken into consideration. The parameters of the model are calibrated and verified for discrete storms. The combined model is suitable for analysis of inundation on urban areas due to overflow of storm sewers and flooding caused by failure of pumping stations. Simulated results can be applied to establish flood-mitigation measures. (C) 2000 Elsevier Science B.V. All rights reserved.
\end{abstract}

Keywords: Urban hydrology; Inundation; Storm sewer system; Overland flow; Pumping station operation; Flood mitigation measure

\section{Introduction}

In rural areas such as agricultural fields or slope lands, surface overland flow processes, which are primarily determined by the topography, land cover, and soil type, can be appropriately simulated by the two-dimensional (2D) diffusive overland-flow model based on non-inertia surface flow dynamics (Hromadka and Lai, 1985; Wasantha Lal, 1998). For the case of urbanized areas, surface overland flow process is altered by anthropogenic factors such as

\footnotetext{
* Corresponding author. Tel:+886-2-23622977; fax:+886-223635854.

E-mail address: tjchang@ccms.ntu.edu.tw (T.J. Chang).
}

land use and storm drainage systems. The surface runoff rate and volume are increased due to more impervious areas like rooftops, squares, and roads. Overland flow direction is also changed by manmade facilities such as drainage systems, roads, and buildings. As a result, surface runoff phenomena of urbanized areas are different from those in rural areas.

Urban surface runoff smaller than the design capacity of the storm drainage system, including storm sewers and pumping stations, is drained into underground sewers. Surface inundation does not occur. The 2D diffusive overland-flow model used in rural areas does not need to be employed since storm sewers drain all of the surface runoff that flows into inlets. The Storm Water Management Model 


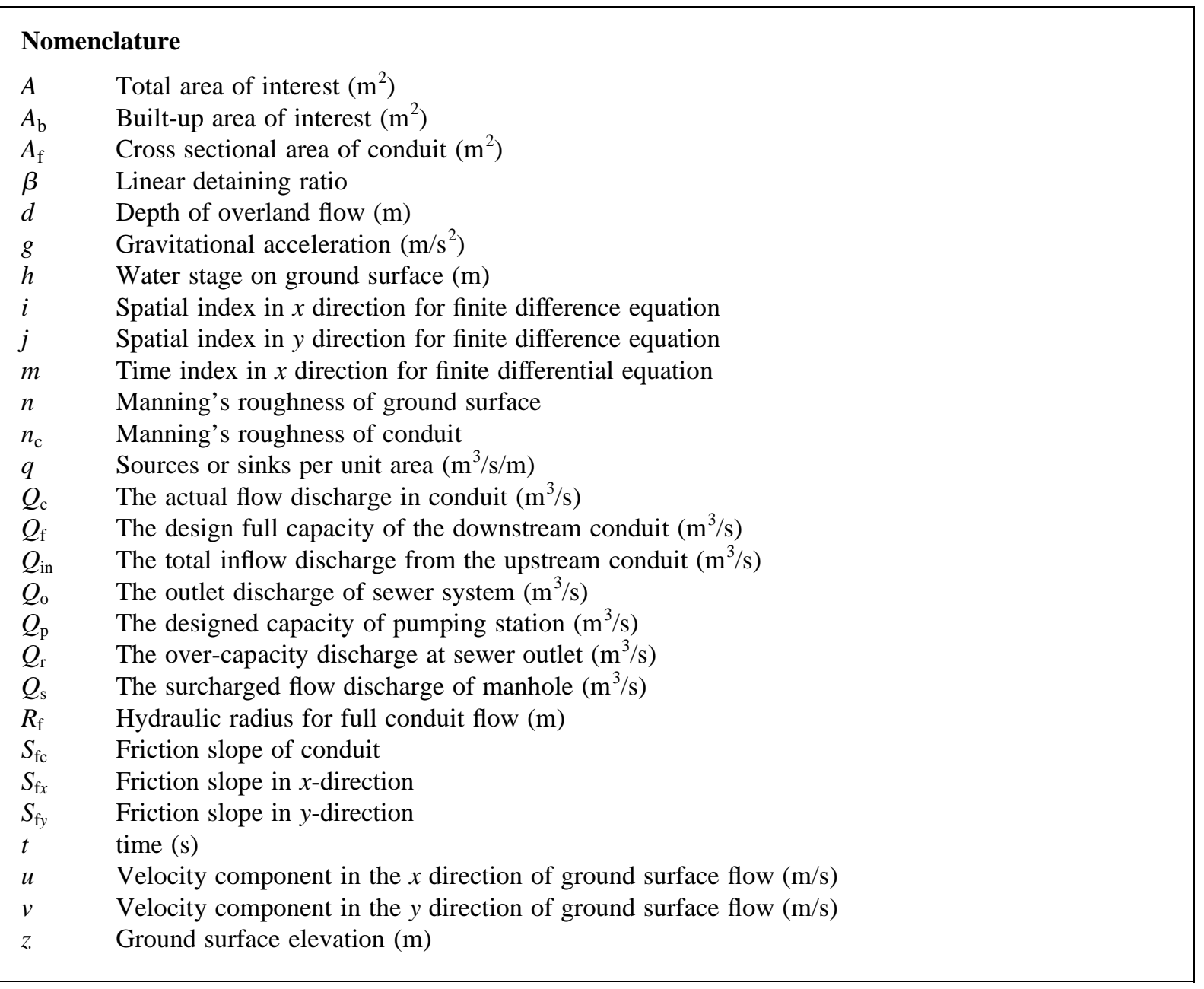

(SWMM) developed by US EPA (Huber and Dickinson, 1988) is adequate to simulate the water flow in drainage sewer systems. On the other hand, for surface runoff exceeding the design capacity of the storm drainage system, water overflows from storm sewers through manholes or outlet pumping stations onto land surface and hence inundation occurs. SWMM can only provide hydrographs at surcharged manholes. Other advanced software like MOUSE (Danish Hydraulic Institute, 1999) and HydroWorks (HR Wallingford Ltd, 1997) also give conceptual flood depths by water level or volume-depth rating curve. None can give the detailed dynamic information on surface inundation zones and depths. Consequently, a new urban inundation model, combining a storm sewer system model, a 2D diffusive overland-flow model and operations of pumping stations, is necessary to simulate the surcharge-induced inundation in urban areas.

As for the computation of the discharge in storm sewer systems, various numerical models have become available. Yen and Akan (1999) provided an excellent review of storm sewer modeling. Lager and Smith (1974), Huber (1975) and Marsalek et al. (1975) using storm sewer models and comparing the simulated and observed results for various urban areas have indicated that the agreement was found to be good for SWMM and ILLUDAS, and good to fair for others. In this study, SWMM is adopted for the computation of water flow in storm sewer systems and surcharged hydrographs at manholes. 
Regarding to 2D inundation models, the mathematical equations governing flows over watershed surface are the dynamic wave equations. Lai (1986) gave a complete survey of different numerical schemes. However, it is difficult to use the dynamic wave equations for the analysis of distributed surface inundation due to adverse slope and irregular geometry in floodplain (Tayfur et al., 1993). When the effect of inertial terms is relatively apparent, such as dambreak flows or rapidly rising stage in channels, the dynamic wave equations must be completely considered. Otherwise, a simplified form of the dynamic wave equations, the non-inertia wave (diffusion wave) model that neglects the inertial terms but considers the backwater effect, is physically applicable to simulate slow regional overland flow in floodplains. Fennema et al. (1994) found the non-inertia flow is suitable for modeling of regional flow conditions. Akan and Yen (1981) and Hromadka and Lai (1985) have shown that the non-inertia wave equations can accurately represent many natural flow situations. Yen et al. (1989) and Wasantha Lal (1998) compared the performance of various numerical schemes on the 2D non-inertia wave equations, including the explicit scheme, the simply explicit scheme (SES), the alternating direction implicit scheme (ADI), the linear successive over-relaxation scheme (SOR), and the alternating direction explicit scheme (ADE). The ADE scheme has relatively short run time and is appropriate when high accuracy is not a priority. In this study, a 2D diffusive overland-flow model with ADE method is applied. The 2D diffusive overland-flow model is modified according to various urban land uses and artificial facilities (Hsu et al., 1990).

The lowlands along the Tanshui River passing through the metropolitan Taipei City in northern Taiwan are densely populated and protected by levees along the banks with a 200-year return period protection level. The water stages in river channels are usually higher than those of storm sewer flow and overland flow in the lowlands during the periods of storm events. It is not feasible to drain the surface runoff by gravity, and hence pumping stations were constructed. As a result, urban storm sewer systems in Taipei are composed of storm sewer pipelines and their outlet pumping stations, which are all designed for a 5-year return period rainfall. For the return period of storm events between 5 and 200 years, the urban area in Taipei is protected against river flooding, but surcharged water from Taipei storm sewer systems through manholes or outlet pumping stations flows onto urban land surface, resulting in serious inundation. Therefore, in this study, a new urban inundation model, combining a storm sewer system model, a 2D diffusive overland-flow model, and operations of pumping stations, was developed to simulate the surcharge-induced inundation in Taipei.

\section{Urban inundation model}

To simulate the inundation of urban areas, the flow process in the inundation area is divided into two components, namely the surcharge and inundation components. For the former, SWMM was modified and applied for computation of flows in storm sewer systems and surcharged flow at manholes. For the latter, a 2D diffusive overland-flow model is employed for surface runoff and inundation simulation.

\subsection{Storm water management model}

The SWMM, developed under the support of US EPA, is commonly applied for quality and quantity processes of runoff in urbanized area. SWMM contains several blocks for analysis of different process. Two of them are used in this study, the RUNOFF and EXTRAN blocks (Huber et al., 1984; Huber and Dickinson, 1988). The RUNOFF block performs hydrologic simulation and its outputs are taken as input to the EXTRAN block, which routes the conduit flow in a storm sewer system using an explicit numerical solution of the SaintVenant equations.

The amount of surcharged flow is defined as $Q_{\mathrm{s}}=$ $Q_{\text {in }}-Q_{\mathrm{f}}$, in which $Q_{\text {in }}$ is the total inflow discharge from the upstream conduit, and $Q_{\mathrm{f}}$ is the design full capacity of the downstream conduit, defined as

$Q_{\mathrm{f}}=\frac{1}{n_{\mathrm{c}}} A_{\mathrm{f}} R_{\mathrm{f}}^{2 / 3} S_{\mathrm{f}}^{1 / 2}$,

where $n_{\mathrm{c}}$ is the Manning's roughness of conduit, $A_{\mathrm{f}}$ the full cross section area of conduit, $R_{\mathrm{f}}$ the hydraulic radius for full conduit flow, and $S_{\mathrm{fc}}$ the friction slope of conduit. 


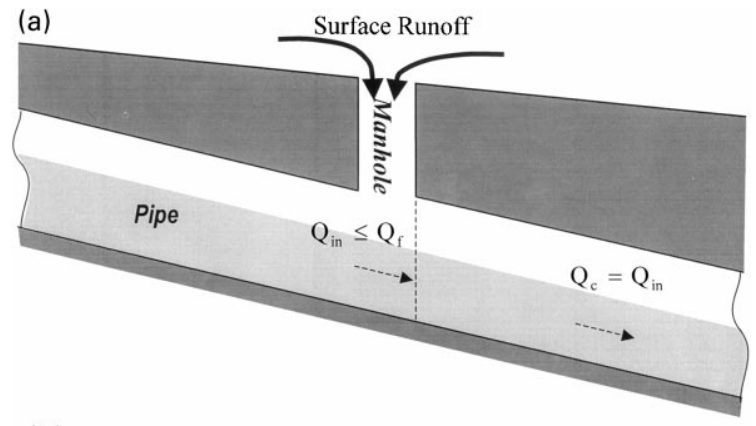

(b)

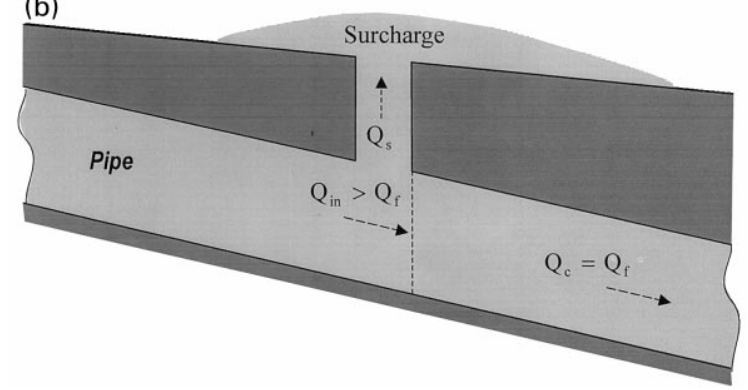

Fig. 1. Schematic of normal urban drainage and surcharge-induced inundation. (a) Inflow discharge below the conduit capacity. (b) Inflow discharge greater than the conduit capacity.

For the condition when the total inflow discharge $Q_{\text {in }}$ does not exceed the design outflow capacity $Q_{\mathrm{f}}$ as shown in Fig. 1(a), the actual discharge in the conduit, $Q_{\mathrm{c}}=Q_{\mathrm{in}}$, is drained through the downstream conduit without surcharge. When the conduit surcharges (shown as Fig. 1(b)), only a part of discharge, $Q_{\mathrm{c}}=$ $Q_{\mathrm{f}}$, can be drained by the downstream outflow conduit. The rest of the discharge, $Q_{\mathrm{s}}=Q_{\text {in }}-Q_{\mathrm{f}}$, which is in excess the design capacity, surcharges through the manhole onto ground surface. SWMM can give hydrographs for each surcharged manhole; however, it cannot deal with detailed information such as inundation zones and depths caused by surcharged water. However, such information, which is indispensable for engineering design and flood mitigation measures. The distribution of surcharged water is treated in next section using the $2 \mathrm{D}$ diffusive overland-flow model.

\section{2. $2 D$ diffusive overland-flow model}

Assuming that acceleration term of water flow on the urban surface is small compared to gravitation and friction terms, the inertial term in motion equations is neglected. The depth-averaged shallow water equations on land surface can be written as:

$$
\begin{aligned}
& \frac{\partial d}{\partial t}+\frac{\partial[(1-\beta) u d]}{\partial x}+\frac{\partial[(1-\beta) v d]}{\partial y}=q, \\
& -\frac{\partial h}{\partial x}=S_{\mathrm{f} x}+\frac{q u}{d g} \\
& -\frac{\partial h}{\partial x}=S_{\mathrm{f} y}+\frac{q v}{d g}
\end{aligned}
$$

where $d$ is the depth of flow, $h$ the water stage, $u$ the velocity component in $x$-direction, $v$ the velocity component in $y$-direction, $t$ the time, $g$ the gravitational acceleration, $q$ the source or sink per unit area (the surcharge and outlet discharge calculated from SWMM are treated as source, and pumping discharge as sink),

$S_{\mathrm{f} x}=\frac{n^{2} u \sqrt{u^{2}+v^{2}}}{d^{4 / 3}}$

is friction slope in $x$-direction,

$$
S_{\mathrm{f} y}=\frac{n^{2} v \sqrt{u^{2}+v^{2}}}{d^{4 / 3}}
$$

is friction slope in $y$-direction, $n$ is Manning's roughness, and $\beta=\sqrt{A_{\mathrm{b}} / A}$ is detaining ratio which represents a linear ratio of building area to the total area of interest. For computational convenience, we further assume that $|u|$ and $|v|$ is instead of $\sqrt{u^{2}+v^{2}}$ for computing friction slopes $S_{\mathrm{f} x}$ and $S_{\mathrm{fy}}$, respectively.

In the present study, a two-step alternating direction explicit method was adopted. The finite difference equations, derived from Eqs. (1)-(3) in each time step, are as in the following sections.

\subsubsection{For the first time step $(m+1 / 2)$}

$$
\begin{aligned}
& d_{i, j}^{m+1 / 2}= \\
& d_{i, j}^{m}-\frac{\Delta t}{2}\left\{\frac{(1-\beta)\left[\left(d^{m} u^{m+1 / 2}\right)_{i+1 / 2, j}-\left(d^{m} u^{m+1 / 2}\right)_{i-1 / 2, j}\right]}{\Delta x}\right. \\
& \left.\quad+\frac{(1-\beta)\left[(d v)_{i, j+1 / 2}^{m}-(d v)_{i, j-1 / 2}^{m}\right]}{\Delta y}-q_{i, j}^{m+1 / 2}\right\}
\end{aligned}
$$




$$
\begin{aligned}
& \frac{\left[(d+z)_{i, j}^{m+1 / 2}-(d+z)_{i+1, j}^{m+1 / 2}\right]}{\Delta x} \\
& =\left\{u^{m+1 / 2}\left[\frac{(n)^{2}\left|u^{m+1 / 2}\right|}{\left(d^{m}\right)^{4 / 3}}+\frac{q^{m+1 / 2}}{\left(d^{m} g\right)}\right]\right\}_{i+1 / 2, j} \\
& \underline{\left[(d+z)_{i, j}^{m+1 / 2}-(d+z)_{i, j+1}^{m+1 / 2}\right]} \\
& \quad=\left\{v^{m+1 / 2}\left[\frac{(n)^{2}\left|v^{m+1 / 2}\right|}{\left(d^{m+1 / 2}\right)^{4 / 3}}+\frac{q^{m+1 / 2}}{\left(d^{m+1 / 2} g\right)}\right]\right\}_{i, j+1 / 2}
\end{aligned}
$$

where $m, i$ and $j$ are time, $x$ and $y$ spatial indices, respectively, $\Delta t=t^{m+1}-t^{m}, \Delta x=x_{i+1}-x_{i}, \Delta y=$ $y_{i+1}-y_{i}$. Using Eqs. (4) and (5), $u^{m+1 / 2}$ and $d^{m+1 / 2}$ along $x$-direction can be solved simultaneously. Then $v^{m+1 / 2}$ can be found from Eq. (6).

\subsubsection{For the second time step $(m+1)$}

$$
\begin{aligned}
& d_{i, j}^{m+1}= \\
& d_{i, j}^{m+1 / 2}-\frac{\Delta t}{2}\left\{\frac{(1-\beta)\left[(d u)_{i+1 / 2, j}^{m+1 / 2}-(d u)_{i-1 / 2, j}^{m+1 / 2}\right]}{\Delta x}\right. \\
& +\frac{(1-\beta)\left[\left(d^{m+1 / 2} v^{m+1}\right)_{i, j+1 / 2}-\left(d^{m+1 / 2} v^{m+1}\right)_{i, j-1 / 2}\right]}{\Delta y} \\
& \left.-q_{i, j}^{m+1}\right\} \\
& \frac{\left[(d+z)_{i, j}^{m+1}-(d+z)_{i, j+1}^{m+1}\right]}{\Delta y} \\
& =\left\{v ^ { m + 1 } \left[\frac{(n)^{2}\left|v^{m+1}\right|}{\left.\left.\left(d^{m+1 / 2}\right)^{4 / 3}+\frac{q^{m+1}}{\left(d^{m+1 / 2} g\right)}\right]\right\}_{i, j+1 / 2}}\right.\right. \\
& \frac{\left[(d+z)_{i, j}^{m+1}-(d+z)_{i, j+1}^{m+1}\right]}{\Delta x}\left[u ^ { m + 1 } \left[\frac{(n)^{2}\left|u^{m+1}\right|}{\left.\left.\left(d^{m+1}\right)^{4 / 3}+\frac{q^{m+1}}{\left(d^{m+1} g\right)}\right]\right\}_{i+1 / 2, j}}\right.\right.
\end{aligned}
$$

In the second time step, Eqs. (7) and (8) are used to solve $v^{m+1}$ and $d^{m+1}$ along $y$-direction and Eq. (9) is employed to solve $u^{m+1}$ directly.

\subsection{Model linkage}

The flow chart of the linkage of the proposed model is depicted in Fig. 2. Firstly, the upland rainfall excess and upland runoff are computed by using the $\phi$ index infiltration method (Musgrave and Holtan, 1964) and HEC-1 model. Next, the computed upland runoff is taken as input to the RUNOFF block of SWMM to calculate the surface runoff discharge hydrographs. The discharge hydrographs are in turn used as the inflow to the storm sewer system for the EXTRAN block simulation of the flow in conduits.

When $Q_{\text {in }}>Q_{\mathrm{f}}$, the discharges $Q_{\mathrm{s}}$ of surcharged flows are introduced into the 2D diffusive overlandflow model to simulate the surface inundation with operation of pumping stations. Since the rainfall in the simulated areas and the runoff from upland areas has already been input into the RUNOFF block of SWMM, the only additional input to the 2D diffusive overland-flow model is the surcharge flow from manholes and outlets of the storm sewer system.

A modification is made to SWMM such that the surcharge flow toward lowlands on the ground surface does not return to the storm sewers. In the EXTRAN block of SWMM, the function of pumping stations can be simulated well. When the outlet discharge $Q_{\mathrm{o}}$ of the sewer system is greater than the capacity of the pumping station, $Q_{\mathrm{p}}$, and the water volume in the detention pond is also over the designed capacity, the backwater effect occurs, and water can overflow through manholes located in upper conduits. Once surcharge occurs, the water would accumulate on ground surface and cannot be drained out immediately from the simulated area.

In the present model, pumping stations are treated as sinks, and the outlets of the sewer system are sources in the 2D diffusive overland-flow model. For the situation $Q_{\mathrm{o}} \leq Q_{\mathrm{p}}$, the outlet flow $Q_{\mathrm{o}}$ is immediately drained out by the pumping station. Otherwise, the over-capacity discharge, $Q_{\mathrm{r}}=Q_{\mathrm{o}}-Q_{\mathrm{p}}$, overflows from the outlet of the conduit. Inundation starts from the detention pond and diffuses toward neighboring areas. Latter, as the conduit discharge $Q_{\mathrm{o}}$ falls below the design capacity $Q_{\mathrm{p}}$ again, water in the detention pond is drained out by the pumping station. 


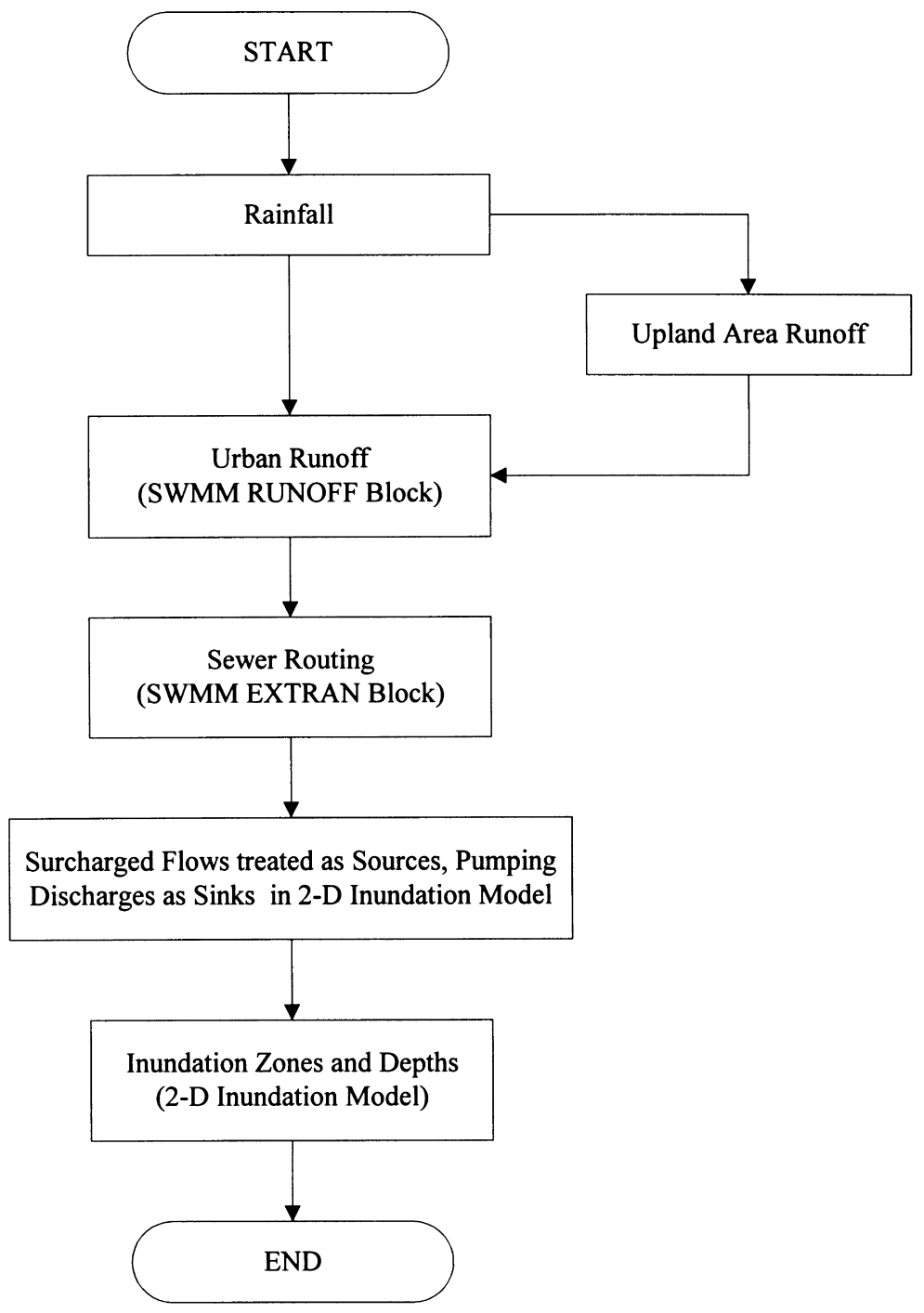

Fig. 2. Flow chart of model linkage.

The surface runoff that returns to the detention pond is pumped out of the simulated area. The present simulation fits the physical phenomenon better than simulating the function of pumping stations with the EXTRAN block of SWMM.

\subsection{Boundary conditions}

On the boundaries along the levees, the lateral inflows into the boundaries are set equal to zero. In other words, the levees are assumed to be high enough, to prevent river water inflow into the simulation area. Assuming that the pumping stations work normally with full capacity during simulation, they are treated as sinks in the 2D inundation model.

\section{Model verification}

The City of Taipei is located in the center of the Taipei Basin. It is surrounded by the Tanshui River System, the Tanshui River on the west, Hsintein 


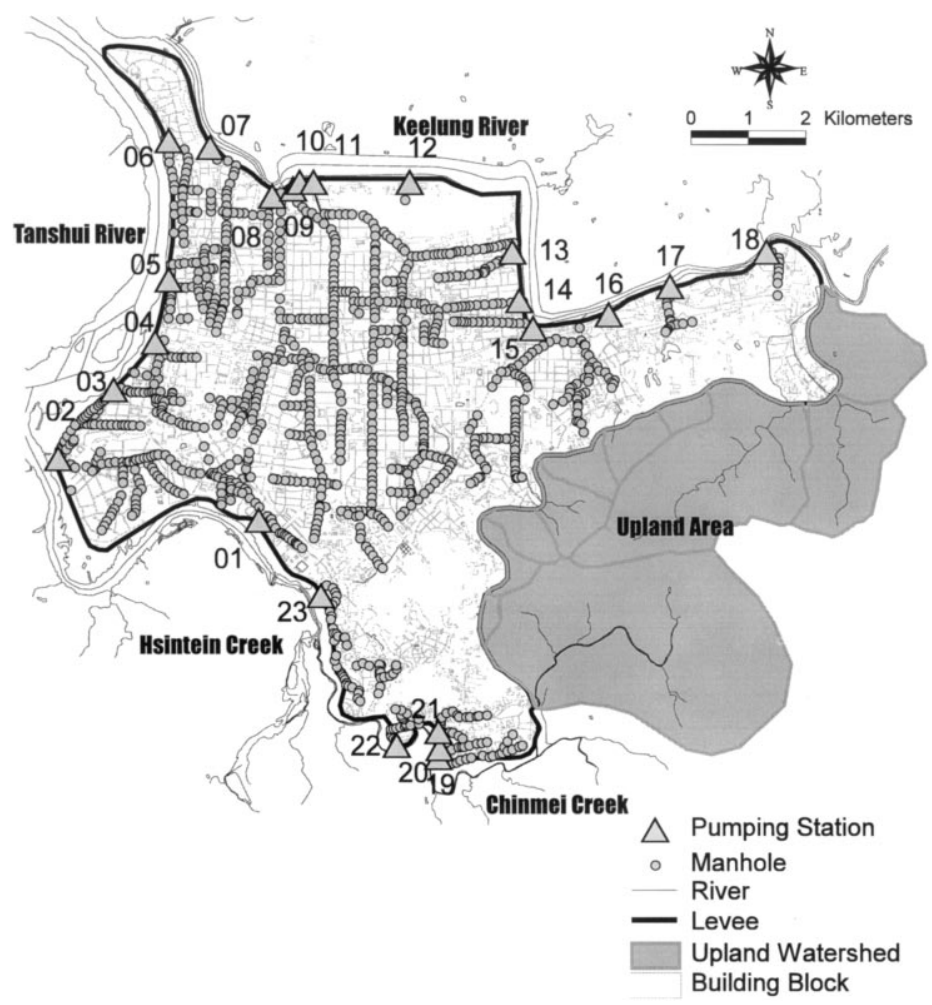

Fig. 3. Storm sewer systems and pumping stations in downtown Taipei.

Creek (a tributary of the Tanshui River) on the south, the Keelung River (also a tributary of the Tanshui River) on the north, and hills on the southeast and east (see Fig. 3). The average elevation of the area is only four meters above the mean sea level and its ground elevation decreases mildly northward with a slope of approximately $0.1 \%$. The lowlands along the Tanshui River System are densely populated and are protected by levees against the 200-year flood level under the Taipei Flood Control Project. Stormwater in Taipei is drained by storm sewers and pumping stations, which are all designed for a 5-year rainfall. The total capacity of the pumping stations is around $840 \mathrm{~m}^{3} / \mathrm{s}$.

On 15 October 1998, Typhoon Zeb attacked Taiwan. Surcharged water through manholes and pumping stations resulted in serious inundation in Taipei. Thus, this event is taken to verify the present model. Based on earlier studies (Hsu et al., 1990; Hsu, 1992; Lin and Hsu, 1994), Manning's roughness coefficient had been calibrated by land use shown in
Fig. 4. The grid size of the $2 \mathrm{D}$ inundation model is $120 \mathrm{~m} \times 120 \mathrm{~m}$.

There are two rain gauges in the Taipei basin plain, namely Taipei and Chungchengchiao. The two stations are located near to each other and their rainfall records were highly relevant. However, the Chungchenchiao gauge, a new wireless transmission equipped station, is adopted for the real-time flood forecasting system of the Tanshui River Basin. Therefore, the rainfall hyetograph of Typhoon Zeb at the Chungchengchiao Station is employed for model verification and is shown in Fig. 5. The total rainfall was $400 \mathrm{~mm}$ during $30 \mathrm{~h}$, and the peak rainfall intensity was $41 \mathrm{~mm} / \mathrm{h}$. There are no precise records of inundation areas and depth changes during the event. However, inundation zones in Downtown Taipei, which are plotted in Fig. 6(a), were established by the Taipei Government after the event. The simulation results are shown in Fig. 6(b). The inspection of simulation results and surveyed inundation zones reveals that most inundation situations can be well simulated 


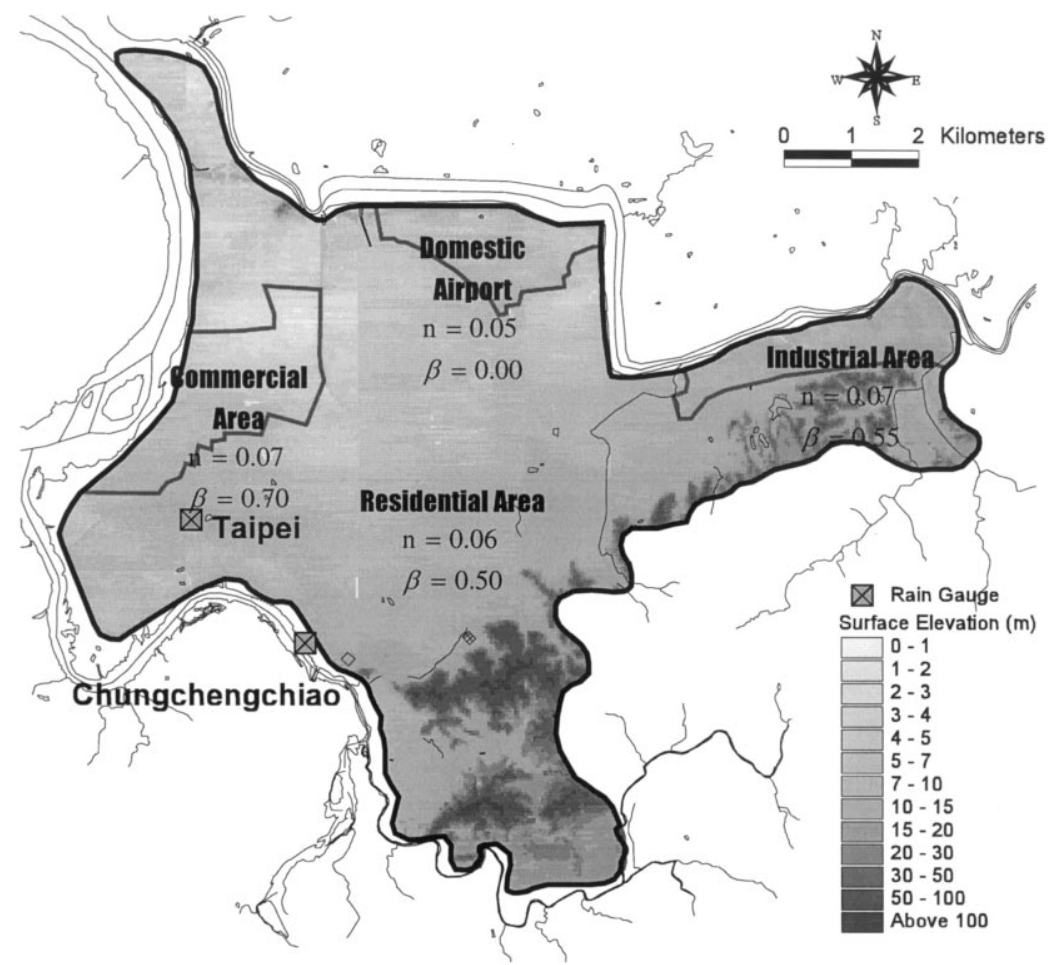

Fig. 4. Digital terrain model, land use and rain gauge stations of Downtown Taipei.

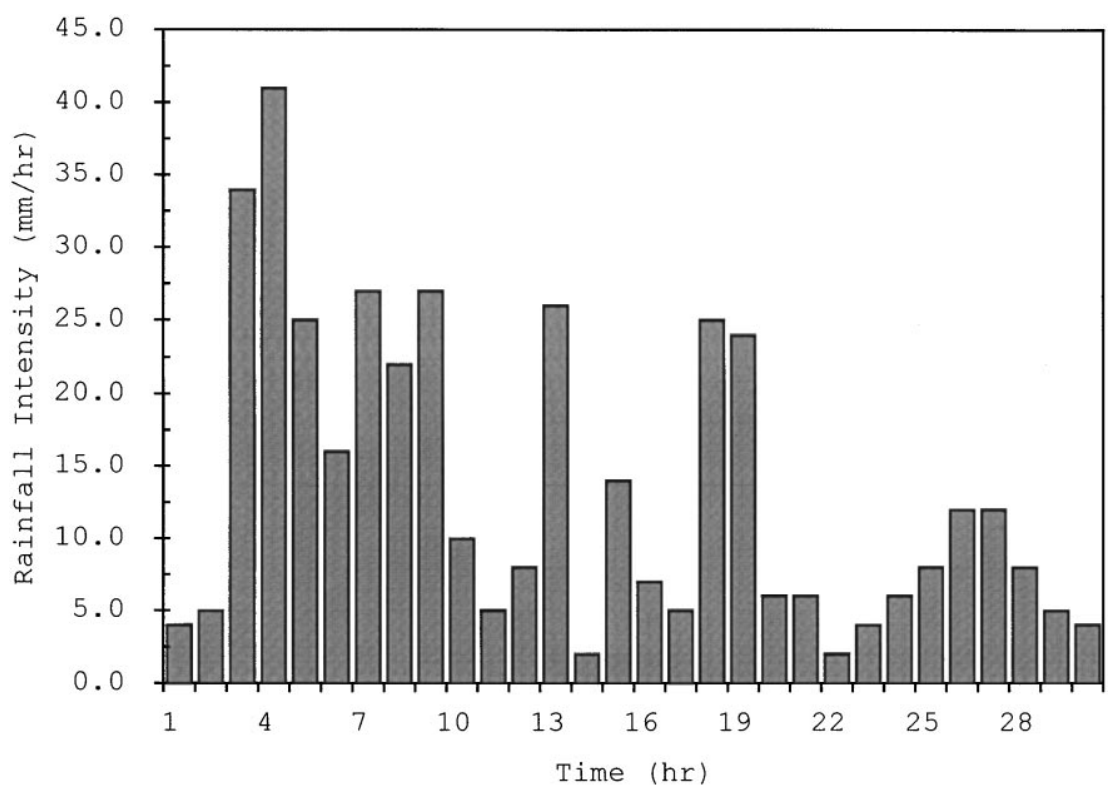

Fig. 5. Rainfall hyetograph of Typhoon Zeb. 
(a)

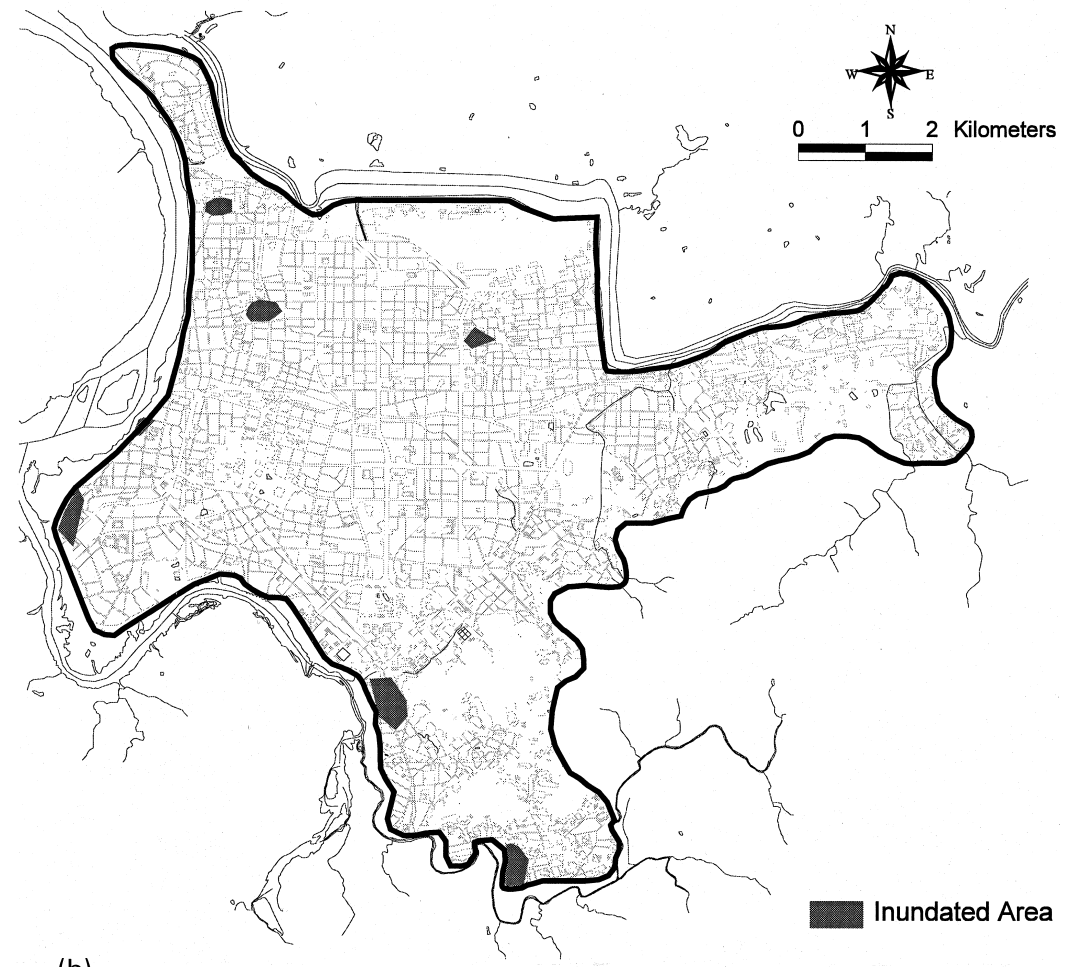

(b)

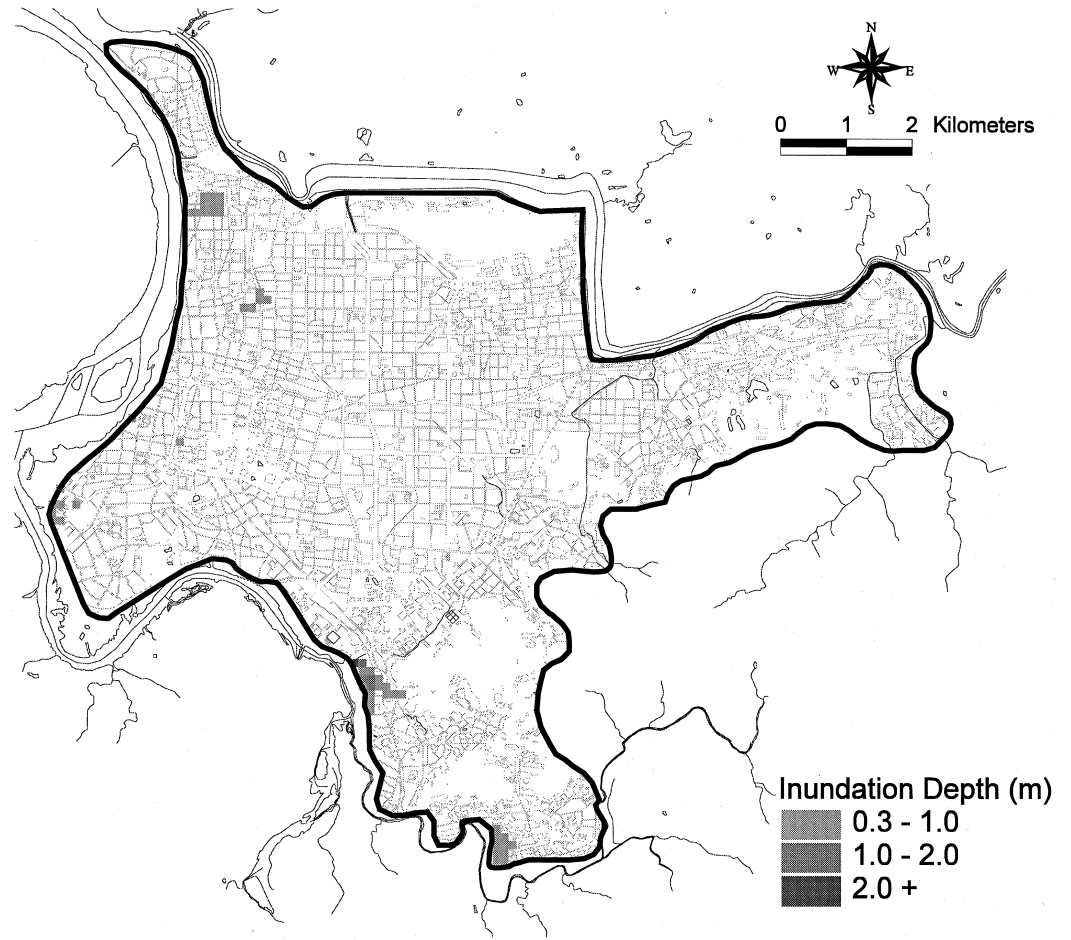

Fig. 6. (a) Surveyed inundation zones of Downtown Taipei for Typhoon Zeb. (b) Simulated inundation zones of Downtown Taipei for Typhoon Zeb. 


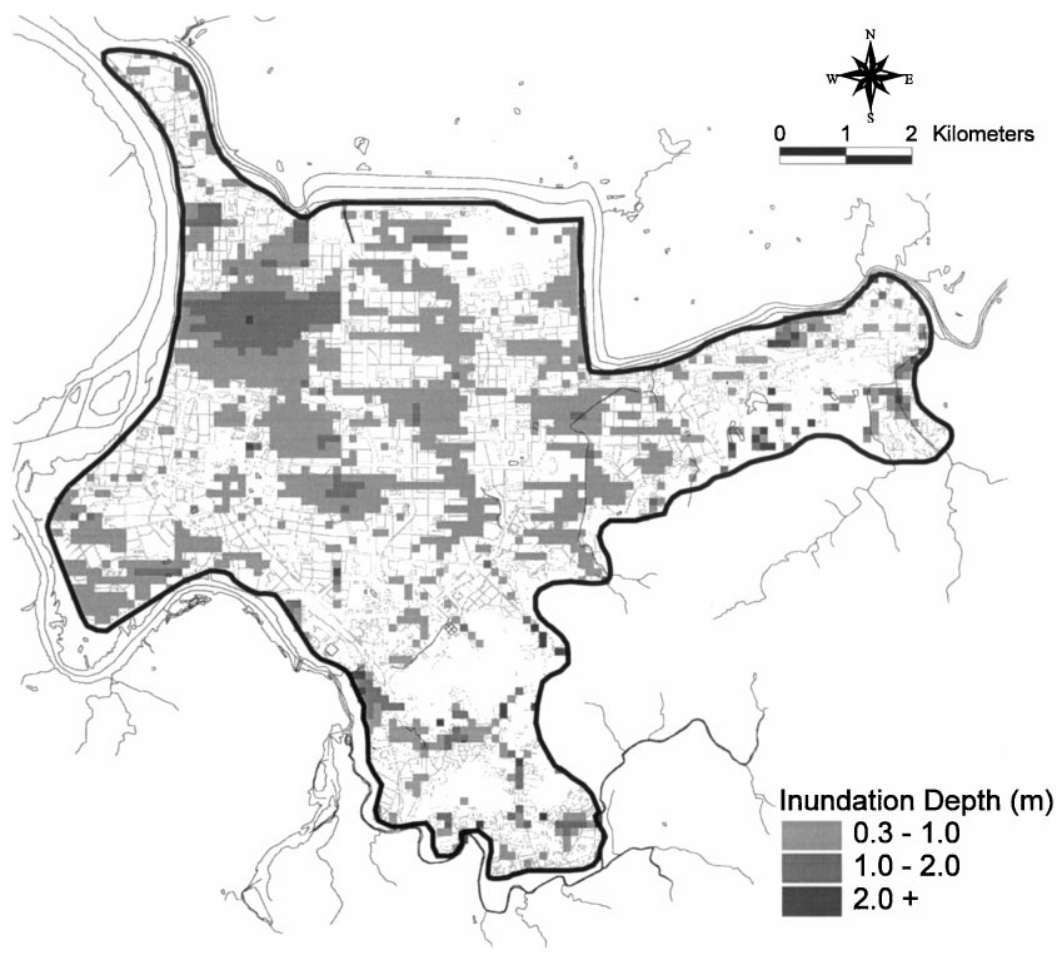

Fig. 7. Simulated inundation zones of Downtown Taipei for Typhoon Zeb without considering Storm Sewer System.

by the model. It should be noted that if the storm sewer system is not taken into consideration in the model, the simulation results, depicted in Fig. 7, show surface runoff as overland flow, which is trapped in lowland areas and causes more serious inundation.

\section{Model applications}

A 100-year, 24-h design rainfall was simulated to analyze surface inundation. The design storm shown in Fig. 8 was generated by using the Alternating Block Method from an intensity-duration-frequency (IDF) curve (Chow et al., 1988). The rainfall records of the Taipei Station, which has more than 53 years of available data length, were used and the log-Pearson Type III distribution was adopted for frequency analysis. The frequency-based rainfall intensity of various durations were obtained and used to determine the IDF curve by Horner's equation. The simulation inundation is shown in Fig. 9. The total rainfall is $505 \mathrm{~mm}$ with a peak rainfall intensity of $78 \mathrm{~mm} / \mathrm{h}$, which is far beyond the rainfall intensity of the Typhoon Zeb event.

\subsection{Detailed dynamic inundation information}

A sub-region named Muchia, located in southern Taipei, and shown in Fig. 10, is taken as an example for the detailed investigation of dynamic inundation. There are three pumping stations numbered Nos. 19, 20 and 21 in the region. The design capacities are 4.0, 8.0 and $15.0 \mathrm{~m}^{3} / \mathrm{s}$, respectively. There are hills in the north of the Muchia region and 200-year flood levees along the Chinmei Creek, a branch of the Hshintein Creek, run along the east, south and west sides. The region is an independent urban drainage area due to the geographic conditions. The surface elevation contours, pumping stations and sewer subsystems are shown in Fig. 10(a).

The simulation results show that nine manholes surcharged between the 9th to 13th hours, six in sewer subsystem No. 19, manhole Nos. 303-306, 308 and 309; and three in sewer subsystem No. 20, 


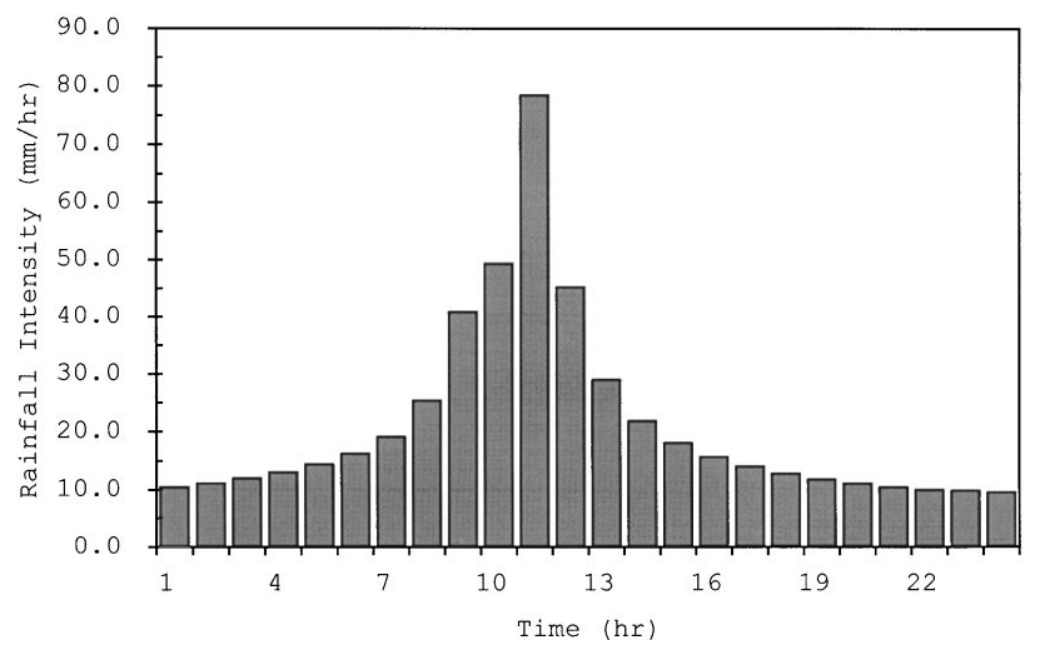

Fig. 8. Rainfall hyetograph for a 100-year $24 \mathrm{~h}$ Storm in Downtown Taipei.

manhole Nos. 303-305. The surcharged discharges of pumping stations and manholes are listed in Table 1.

Table 2 lists the cumulative volume of inflow and outflow of the studied region. The pumping station
(PS) No. 19 drained out $279 \times 10^{3} \mathrm{~m}^{3}$ of water, which is about $68 \%$ of the surcharge volumes from manholes and the outlet of the sewer subsystem, during 24 h. PS No. 20 drained $78 \%$ of the surcharge

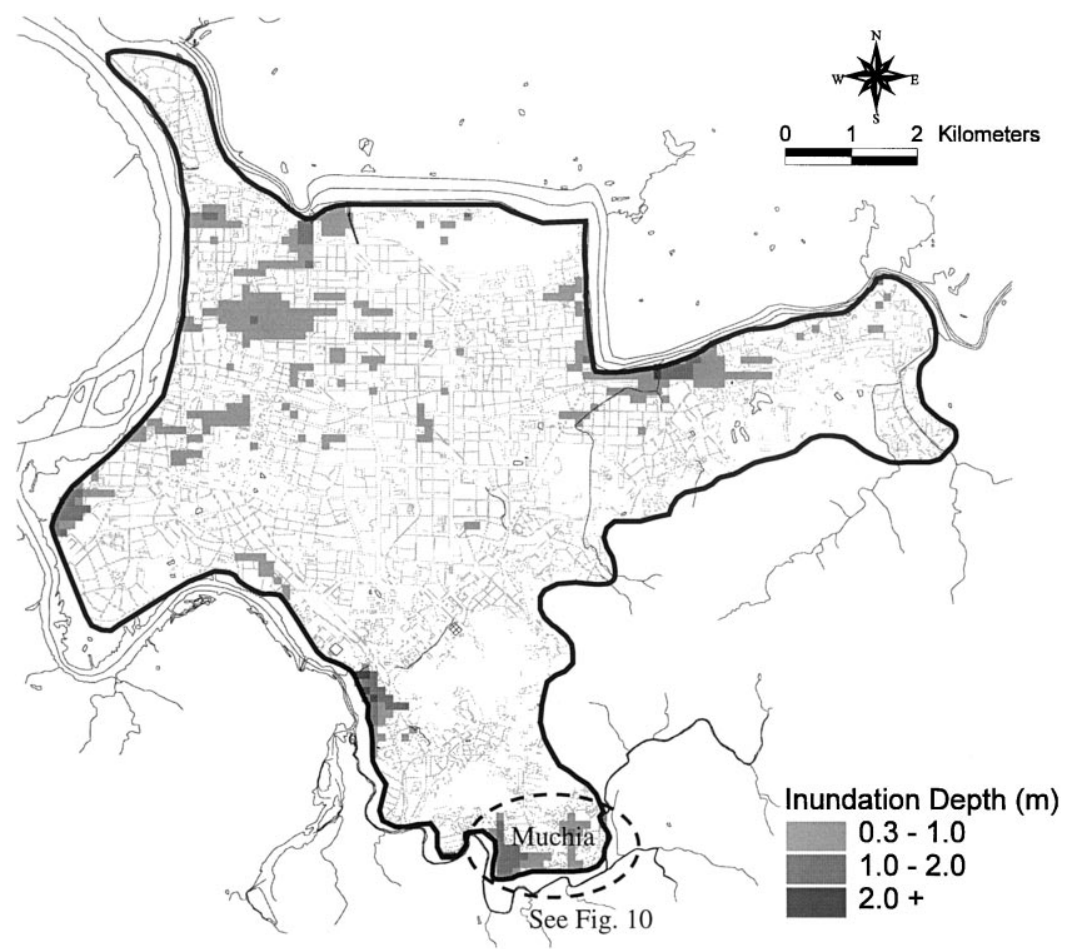

Fig. 9. Simulated inundation of Downtown Taipei with a 100-year, $24 \mathrm{~h}$ rainfall. 

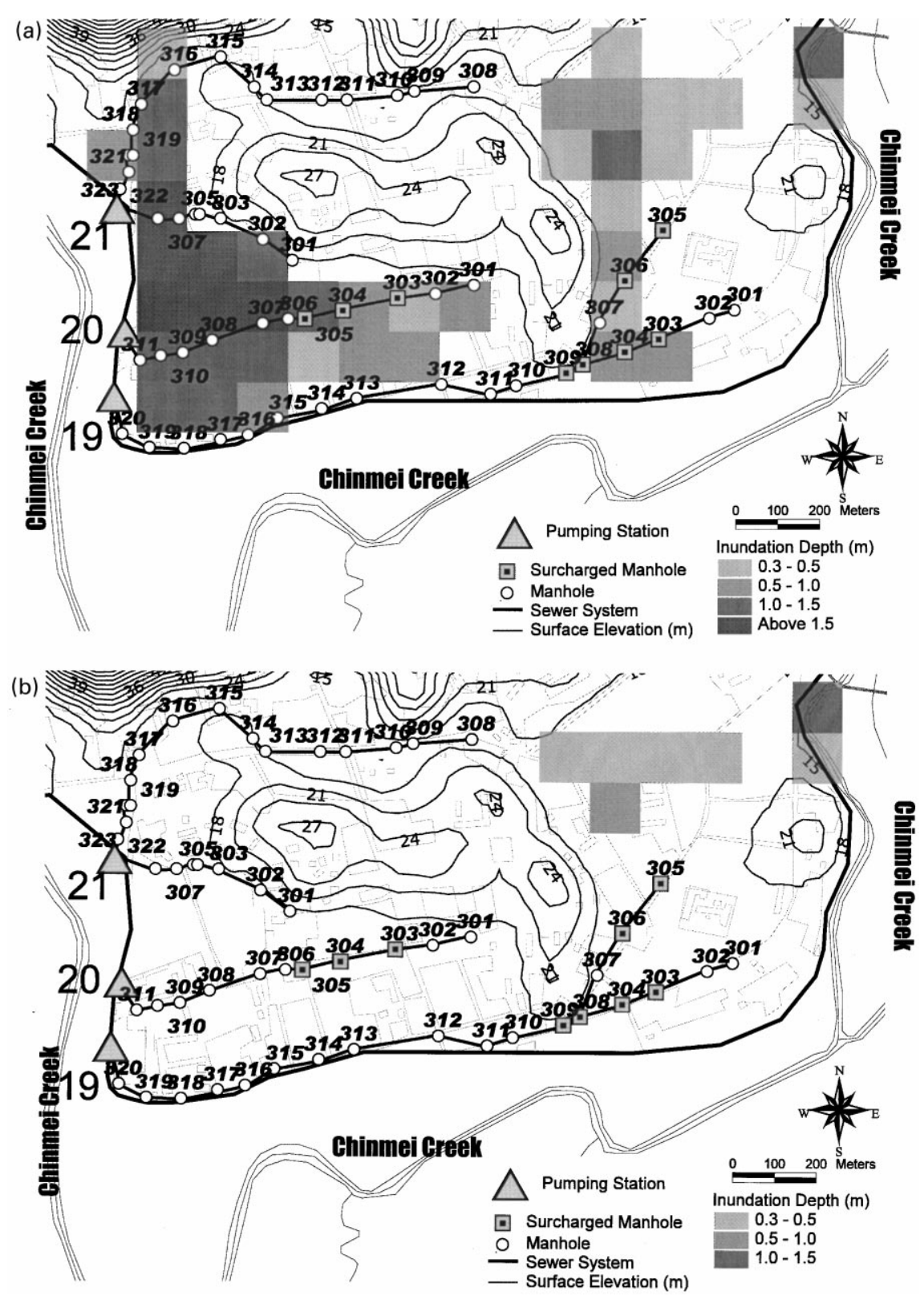

Fig. 10. Simulated local inundation of the Muchia Region with a 100-year, 24 h rainfall: (a) maximum inundation depth; (b) final inundation depth.

volume, but PS No. 21 drained more than $100 \%$ since the 17 th hour. It means that the surcharged flow at Nos. 19 and 20 subsystems tend to flow toward the No. 21 subsystem, resulting in the loading of No. 21 more than $100 \%$.

Fig. 10(a) shows the maximum inundation depths in the Muchia region, the inundated area is about 5.6 ha. The surface elevations of the three pumping stations are similar, but stations Nos. 19 and 20 are about $40 \mathrm{~cm}$ higher than No. 21. The stations Nos. 19 and 20 also have smaller pumping capacities. In other words, a part of the surcharge volume of stations 
Table 1

Surcharge overflow from storm sewers of the Muchia region

\begin{tabular}{|c|c|c|c|c|c|c|c|}
\hline \multirow[t]{3}{*}{ Time (h) } & \multicolumn{7}{|l|}{ Discharge $\left(\mathrm{m}^{3} / \mathrm{s}\right)$} \\
\hline & \multicolumn{2}{|l|}{ Subsystem 19} & \multicolumn{2}{|l|}{ Subsystem 20} & \multicolumn{2}{|l|}{ Subsystem 21} & \multirow[t]{2}{*}{ Total } \\
\hline & $\begin{array}{l}\text { Over-capacity } \\
\text { discharge at } \\
\text { pumping station }\end{array}$ & $\begin{array}{l}\text { Total } \\
\text { manholes } \\
\text { surcharge }\end{array}$ & $\begin{array}{l}\text { Over-capacity } \\
\text { discharge at } \\
\text { pumping station }\end{array}$ & $\begin{array}{l}\text { Total } \\
\text { manholes } \\
\text { surcharge }\end{array}$ & $\begin{array}{l}\text { Over-capacity } \\
\text { discharge at } \\
\text { pumping station }\end{array}$ & $\begin{array}{l}\text { Total } \\
\text { manholes } \\
\text { surcharge }\end{array}$ & \\
\hline 8 & 1.74 & 0 & 0.91 & 0 & 0 & 0 & 0 \\
\hline 9 & 3.31 & 1.61 & 6.83 & 0 & 2.52 & 0 & 14.27 \\
\hline 10 & 3.68 & 4.14 & 11.66 & 0 & 6.05 & 0 & 25.52 \\
\hline 11 & 4.86 & 9.7 & 16.31 & 4.39 & 16.74 & 0 & 51.99 \\
\hline 12 & 3.52 & 5.22 & 12.43 & 0 & 5.69 & 0 & 26.85 \\
\hline 13 & 2.82 & 1.36 & 5.44 & 0 & 0 & 0 & 8.08 \\
\hline 14 & 1.28 & 0 & 1.49 & 0 & 0 & 0 & 0 \\
\hline 15 & 0.26 & 0 & 0 & 0 & 0 & 0 & 0 \\
\hline
\end{tabular}

Table 2

Surcharged and pumped volume of sewer subsystems in the Muchia region

\begin{tabular}{|c|c|c|c|c|c|c|}
\hline \multirow[t]{3}{*}{ Time (h) } & \multicolumn{6}{|c|}{ Cumulative volume $\left(\times 10^{3} \mathrm{~m}^{3}\right)$} \\
\hline & \multicolumn{2}{|c|}{ Subsystem 19} & \multicolumn{2}{|c|}{ Subsystem 20} & \multicolumn{2}{|c|}{ Subsystem 21} \\
\hline & Surcharged & Pumped & Surcharged & Pumped & Surcharged & Pumped \\
\hline 1 & 3 & 3 & 3 & 3 & 6 & 6 \\
\hline 2 & 9 & 9 & 11 & 11 & 17 & 17 \\
\hline 3 & 17 & 17 & 22 & 22 & 32 & 32 \\
\hline 4 & 26 & 26 & 36 & 36 & 49 & 49 \\
\hline 5 & 36 & 36 & 53 & 53 & 68 & 68 \\
\hline 6 & 47 & 47 & 72 & 72 & 90 & 90 \\
\hline 7 & 60 & 60 & 95 & 95 & 117 & 117 \\
\hline 8 & 86 & 74 & 127 & 124 & 154 & 154 \\
\hline 9 & 128 & 89 & 181 & 153 & 217 & 209 \\
\hline 10 & 190 & 103 & 267 & 182 & 293 & 263 \\
\hline 11 & 241 & 118 & 355 & 211 & 407 & 317 \\
\hline 12 & 273 & 132 & 428 & 239 & 482 & 371 \\
\hline 13 & 297 & 146 & 477 & 268 & 530 & 425 \\
\hline 14 & 316 & 161 & 511 & 297 & 565 & 479 \\
\hline 15 & 332 & 175 & 538 & 326 & 593 & 533 \\
\hline 16 & 344 & 190 & 560 & 355 & 616 & 587 \\
\hline 17 & 355 & 204 & 578 & 383 & 636 & 641 \\
\hline 18 & 365 & 218 & 595 & 412 & 653 & 695 \\
\hline 19 & 373 & 233 & 610 & 441 & 669 & 749 \\
\hline 20 & 381 & 247 & 623 & 470 & 683 & 803 \\
\hline 21 & 388 & 259 & 635 & 489 & 696 & 855 \\
\hline 22 & 395 & 265 & 646 & 500 & 708 & 880 \\
\hline 23 & 401 & 271 & 657 & 510 & 720 & 899 \\
\hline 24 & 408 & 277 & 667 & 520 & 731 & 914 \\
\hline 25 & 408 & 277 & 667 & 520 & 731 & 917 \\
\hline 26 & 408 & 277 & 668 & 520 & 731 & 919 \\
\hline 30 & 408 & 278 & 668 & 520 & 731 & 923 \\
\hline 34 & 408 & 278 & 668 & 520 & 731 & 925 \\
\hline 38 & 408 & 278 & 668 & 520 & 731 & 926 \\
\hline 42 & 408 & 279 & 668 & 520 & 731 & 927 \\
\hline
\end{tabular}



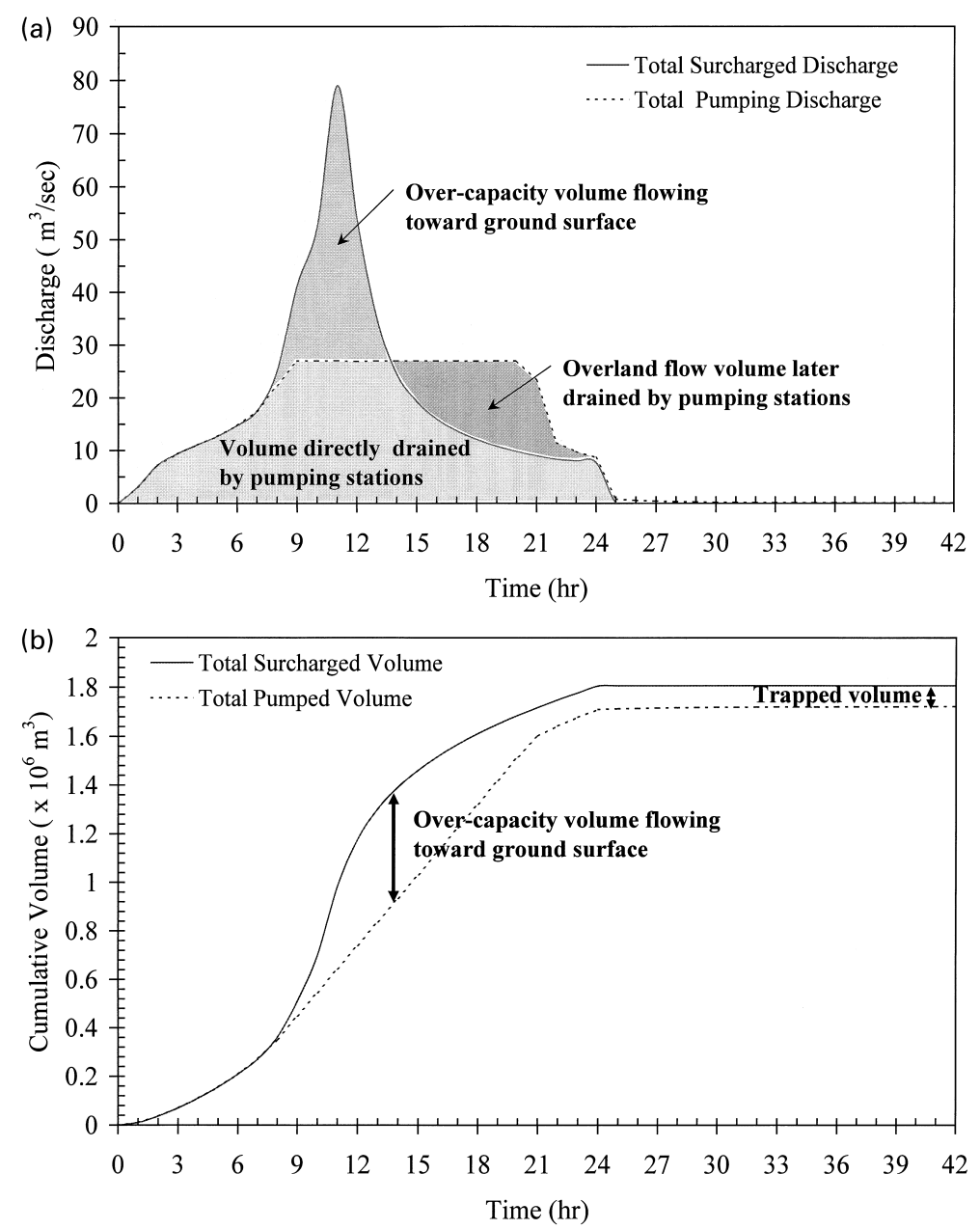

Fig. 11. (a) Total surcharged and pumping discharge of the Muchia region. (b) Cumulative surcharged and pumped volume of the Muchia region.

Nos. 19 and 20 that flows toward No. 21 due to higher surface elevations and water heads is drained by station No. 21. If the surcharge volume at each subsystem can only be drained out by its pumping station, obviously, from Table 2, it would take much longer for station Nos. 19 and 20 to drain out the surcharge volumes. Combined operation of these three pumping stations can shorten the inundation duration.

There are nine surcharged manholes and three pumping stations in the Muchia region. Fig. 11(a) shows the total surcharge discharge and total pumping hydrographs of the Muchia region. It clearly shows that the total surcharged discharge exceeds the total capacity of the pumping stations during the period from 8.2 to $13.7 \mathrm{~h}$. Water cannot be drained out immediately, although the stations are in full operation. The over-capacity discharge flowing from sewer outlets and manholes toward neighboring areas accumulates on ground surface and causes inundation. After the surcharged flow at sewer outlets are decreased below the pumping capacities, the water accumulated on nearby grounds returns to the conduit outlets and will be drained out later.

It should be pointed out that some surcharge flow cannot reenter the conduit outlets, because of irregular topography of ground surface. Fig. 10(b), showing the final inundation depth of the Muchia region, explains this phenomenon. There are several grid areas 


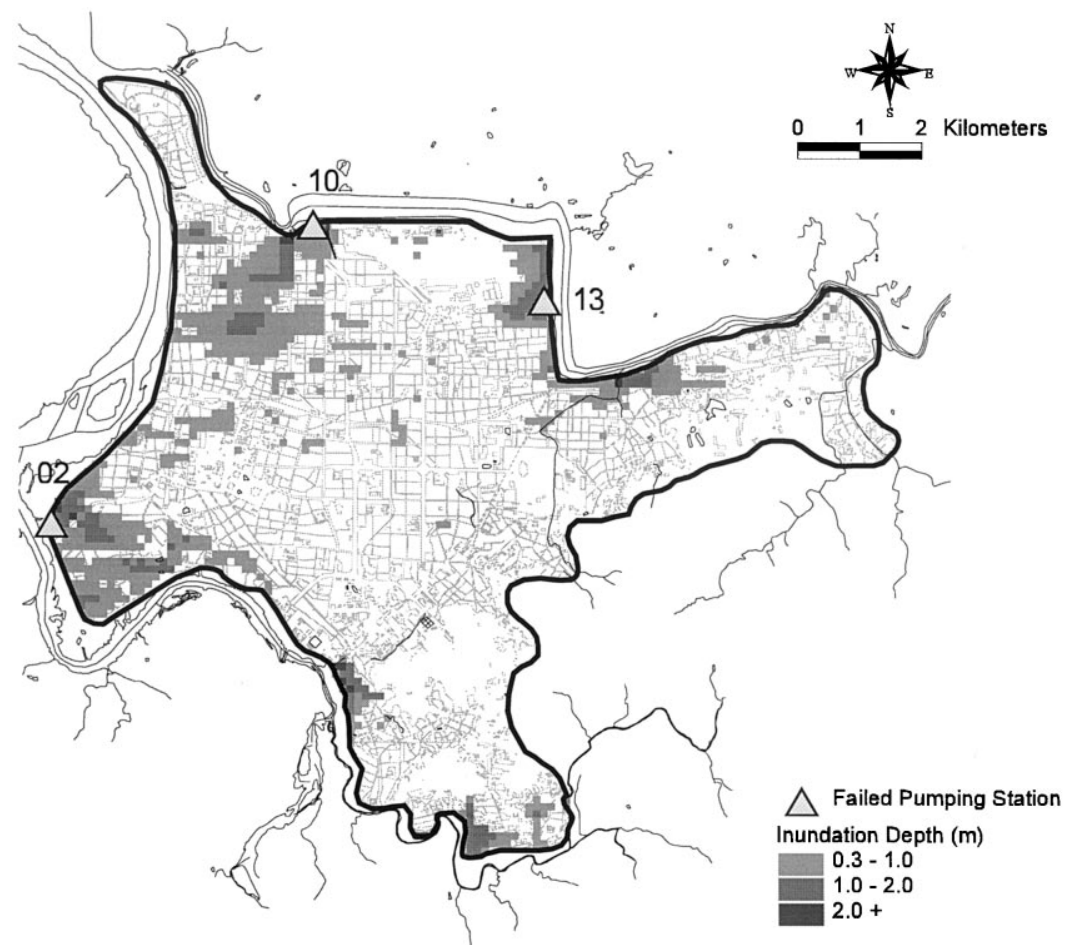

Fig. 12. Simulated inundation for 3-stations failure of Downtown Taipei.

showing a final inundation depth, since these areas have lower surface elevations than their neighboring areas. This is referred to as a "trapped volume", which is the difference of the final cumulative inflow and outflow volumes depicted in Fig. 11(b).

\subsection{Hazards scenario simulation}

The model can also simulate hazard scenarios. Fig. 12 shows the simulated inundation for a 100-year 24-h design rainfall and failures of three pumping stations, Nos. 02,10 and 13, with capacities of 33.1, 53.0, and $25.0 \mathrm{~m}^{3} / \mathrm{s}$, respectively. Fig. 13(a) shows that the failure of three pumping stations results in the peak pumping discharge decreasing from 649 to $541 \mathrm{~m}^{3} / \mathrm{s}$. This difference is very close to the total capacity of $111 \mathrm{~m}^{3} / \mathrm{s}$ of the three pumping stations. The maximum total inundation volume increases from $3.95 \times 10^{6}$ to $6.24 \times 10^{6} \mathrm{~m}^{3}$, and the final inundation volume (trapped volume) also increases from $2.00 \times 10^{6}$ to $5.33 \times 10^{6} \mathrm{~m}^{3}$. They are plotted in Fig. 13(b). The increased trapped volume is about equal to the total pumped volume of these three pumping stations working $9 \mathrm{~h}$ at full capacity. Obviously, the total inundated area increases from 616 ha (Fig. 9) to 1044 ha (Fig. 12). Some of the residential and commercial areas are inundated because of the failures of pumping station Nos. 02 and 10, which may cause human life and financial losses. Some other facilities, like the domestic airport area (Fig. 4) near the pumping station No. 13 , would be seriously inundated due to failures of the pumping stations, resulting in air traffic interruption. The simulation result helps water managers plan the hazard mitigation strategy and choose remedies.

\section{Summary and conclusion}

An urban inundation model has been developed to simulate surcharge-induced inundation in urban areas. In the model, SWMM is used to compute storm sewer flow and surcharge overflow through manholes. A 2D diffusive overland-flow routing is performed to simulate overland flow on urban 

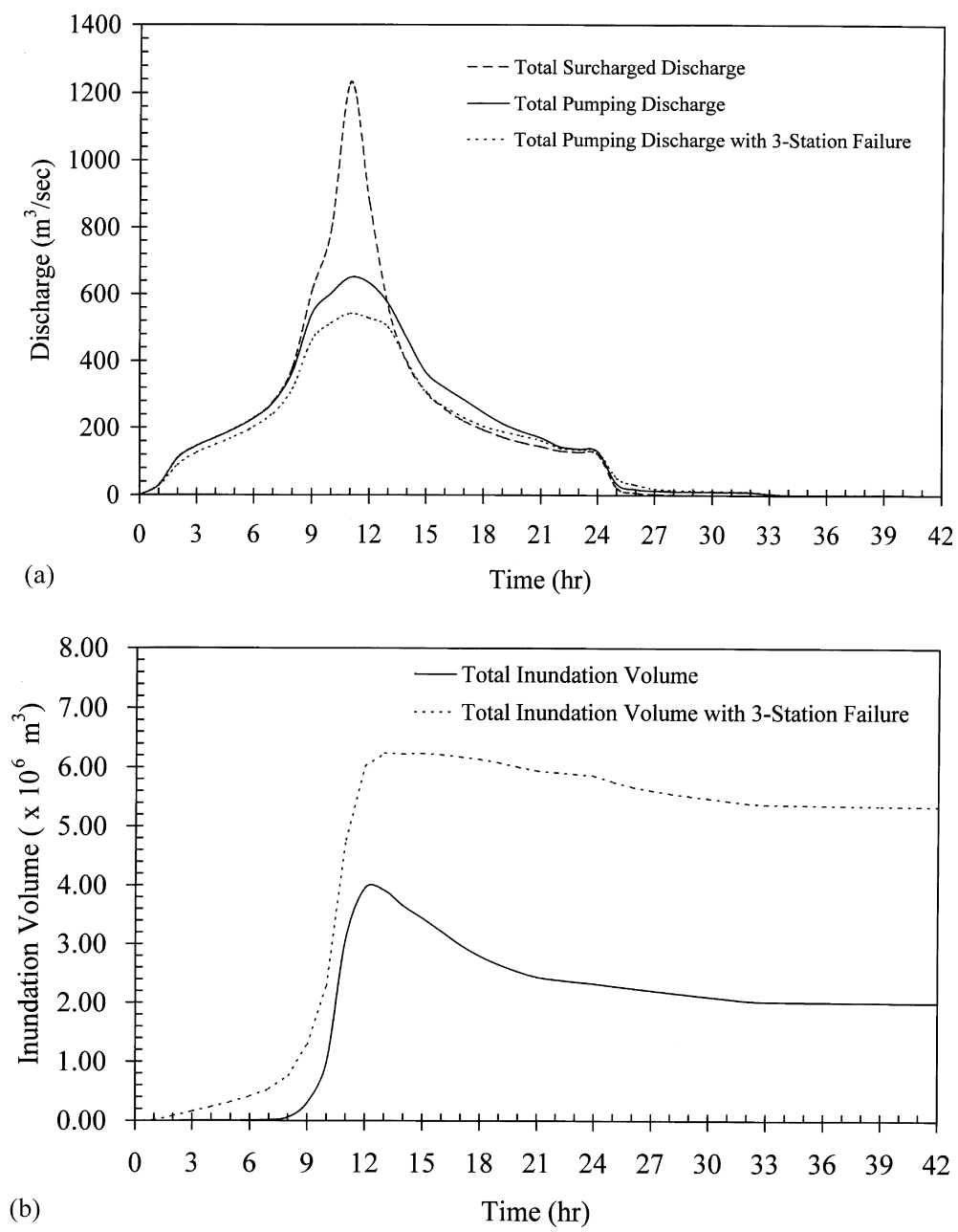

Fig. 13. (a) Total surcharged and pumping discharge of Downtown Taipei. (b) Total inundation volume of Downtown Taipei.

ground surface caused by surcharge. Drainage by pumping at outlets of the storm sewer system has also been taken into consideration. All the components mentioned above could be effectively linked in the model for analyzing inundation in urban areas due to sewer overflows and flooding caused by failure of pumping stations.

The proposed model has been used to study flooding and inundation level in downtown areas of Taipei for design rainfalls of long return periods. Surchargeinduced inundation scenarios for downtown Taipei are emphasized, especially the detailed inundation levels caused by overflows from some important sewer manholes and pumping stations.
The simulation results can help the authority decide preventing flood damages by redesigning and enlarging the capacities of storm sewer systems or the pumping stations in the inundation-prone areas. The model can also be applied to map out the potential inundation and establish flood-mitigation measures as a part of the decision support system for flood control authority.

\section{Acknowledgements}

The work reported herein was supported by the National S\&T Program for Hazards Mitigation 
(NAPHM) of the National Science Council of Taiwan, Republic of China, under grant NSC88-2625-Z-002050. Their support is gratefully acknowledged. The authors are grateful to Professor C.L. Yen, the director of NAPHM, and Professor B.C. Yen at the University of Illinois at Urbana-Champaign for valuable suggestions.

\section{References}

Akan, A.O., Yen, B.C., 1981. Diffusion-wave flood routing in channel networks. Journal of Hydraulics Division, ASCE 107 (6), 719-732.

Chow, V.T., Maidment, D.R., Mays, L.W., 1988. Design storms. Applied Hydrology, vol. 14, McGraw-Hill, New York (chap. 14, pp. 444-492).

Danish Hydraulic Institute, 1999. MOUSE Ver. 1999 User Manual and Tutorial. Hørsholm, Denmark.

Fennema, R.J., Neidrauer, C.J., Johnson, R.A., MacVictor, T.K., Perkins, W.A., 1994. A computer model to simulate natural everglades hydrology. In: Davis, S.M., Ogden, J.C. (Eds.), Everglades, the Ecosystem and its Restoration, St. Lucie Press, pp. 249-289.

Hromadka II, T.V., Lai, C., 1985. Solving the two-dimensional diffusion flow model. Proc. Spec. Conf., sponsed by the Hydr. Div. of ASCE, Lake Buena Vista, Fla.

HR Wallingford Ltd, 1997. HydroWorks: On-Line Manual. Oxon, UK.

Hsu, M.H., 1992. Simulation of inundation with overflow on Levee along Keelung River. Urban Storm Drainage, Proceedoings of the CCNAA-AIT Joint Seminar on Prediction and Damage Mitigation on Meteorologically Induced Natural Disasters. Taipei, Taiwan, pp. 353-363.

Hsu, M.H., Lai, J.S., Yen, C.L.,1990. Two-dimensional inundation model for Taipei city. Proceedings of Fifth International Conference on Urban Storm Drainage. Osaka, Japan, pp. 169174.
Huber, W.C., 1975. Model for Storm Water Strategies. APWA Reporter.

Huber, W.C., Heaney, J.P., Nix, S.J., Dickinson, R.E., Polmann, D.J., 1984. Storm Water Management Model. User's Manual Ver. III, US Environmental Protection Agency.

Huber, W.C., Dickinson, R.E., 1988. Storm Water Management Model. User's Manual Ver. IV, US Environmental Protection Agency.

Lager, J,A., Smith, W.G., 1974. Urban stormwater management and technology —an assessment. US EPA Report, EPA-67012-74040 .

Lai, C.T., 1986. Numerical modeling on unsteady open-channel flow. In: Chow, V.T., Yen, B.C. (Eds.), Advances in Hydroscience, vol. 14. Academic Press, New York, pp. 189-250.

Lin, G.F., Hsu, M.H., 1994. Urban stormwater modeling in Taipei metropolitan area. Proceeding of Republic of China-South Africa Bilateral Symposium on Water Resource, Taipei, Taiwan, pp. 155-166.

Marsalek, J., Dick, T.M., Wisner, P.E., Clarke, W.G., 1975. Comparative evaluation of three urban runoff models. Water Resources Bulletin AWRA 11(2).

Musgrave, G.W., Holtan, H.N., 1964. Infiltration. In: Chow, V.T. (Ed.), Handbook of Applied Hydrology: a Compendium of Water-resources Technology, McGraw-Hill, New York, pp. 12/28-12/30.

Tayfur, G., Kavvas, M.L., Govindaraju, R.S., Storm, D.E., 1993. Applicability of St. Venant equations for two-dimensional overland flows over rough infiltrating surface. Journal of Hydraulic Engineering, ASCE 119 (1), 51-63.

Wasantha Lal, A.M., 1998. Performance comparison of overland flow algorithms. Journal of Hydraulic Engineering, ASCE 124 (4), 342-349.

Yen, B.C., Akan, A.O., 1999. Hydraulic design of urban drainage systems. In: Mays, L.W. (Ed.), Hydraulic Design Handbook, McGraw-Hill, New York.

Yen, C.L., Hsu, M.H., Lai, J.S., 1989. Two-dimensional unsteady flow simulation in flood plain - a comparison between ADE and SES methods. Proceedings of the Computer Applications in Civil and Hydraulic Engineering, Taipei, pp. 1-18. 